Relations industrielles

Industrial Relations

\title{
Academic Contests?
}

Merit Pay in Canadian Universities

Le salaire au mérite dans les universités canadiennes

Concursos Académicos?

Sueldo de acuerdo al mérito en las universidades canadienses

\section{Hugh Grant}

Volume 53, numéro 4, automne 1998

URI : https://id.erudit.org/iderudit/005282ar

DOI : https://doi.org/10.7202/005282ar

Aller au sommaire du numéro

\section{Éditeur(s)}

Département des relations industrielles de l'Université Laval

\section{ISSN}

0034-379X (imprimé)

1703-8138 (numérique)

Découvrir la revue

\section{Citer cet article}

Grant, H. (1998). Academic Contests? Merit Pay in Canadian Universities.

Relations industrielles / Industrial Relations, 53(4), 647-666.

https://doi.org/10.7202/005282ar

Tous droits réservés (C Département des relations industrielles de l'Université Laval, 1998
Ce document est protégé par la loi sur le droit d'auteur. L’utilisation des services d'Érudit (y compris la reproduction) est assujettie à sa politique d'utilisation que vous pouvez consulter en ligne.

https://apropos.erudit.org/fr/usagers/politique-dutilisation/ 


\title{
Academic Contests?
}

\section{Merit Pay in Canadian Universities}

\author{
HUGH GRANT \\ Department of Economics, University of Winnipeg, Winnipeg, Manitoba.
}

This paper examines the application of merit pay in Canadian universities. Designed to motivate and reward greater productivity, the effectiveness of merit pay depends upon the relative importance of competitive versus cooperative behaviour in the academic workplace, the capacity to evaluate individual performance, and the ability to design clear financial signals appropriate to the objectives of the institution. Differences among universities - related to their relative emphasis upon graduate training/research versus undergraduate instruction, their ability to measure performance, and workplace culture - can be expected to produce differences in compensation methods. A logit analysis is conducted that suggests that an institution's likelihood of having a merit pay scheme varies according to region; that it increases with the emphasis placed on graduate training and research; and that it declines in the presence of a unionized faculty association. This suggests that the adoption of performance-based pay is apt to meet stronger resistance in undergraduate and unionized institutions.

Fiscal retrenchment by federal and provincial governments has placed pressure on Canadian universities to create a more market-driven system of higher education. Declining operating grants and greater reliance on tuition fees has meant recruitment and marketing campaigns in the search for enrolments; academic and non-academic programs are now the subject of more intense scrutiny for their "cost effectiveness"; and joint-ventures with private partners receive enhanced priority in research funding. This trend is also apparent in the market for academic labour: terms such as reengineering, outsourcing, downsizing and rightsizing, organizational flattening, and broadbanding are not unfamiliar to univer- 
sity administrators seeking greater flexibility in academic salary determination and greater faculty accountability.

Of the various aspects of faculty compensation systems, merit pay has received the most sustained attention. Performance-based salary awards are not new in North American and British universities, but the reception has been decidedly mixed. Designed to motivate and reward greater productivity, they are, with equal vehemence, embraced as a tangible expression of the "university as meritocracy" (OCUFA 1978), and denounced as Reaganomics encroaching upon the academe (Pratt 1988). Harry Johnson (1974: 26), in his inimitable style, viewed performance-based pay as one avenue for avoiding "the academic vices, evident to the most casual observer of the British, Canadian, and Australian academic scenes, of not working hard enough and of retiring from real work early on the strengths of one early bout of hard work spent on winning a Ph.D. and/or the publication of a promising scientific paper." In contrast, Hamermesh (1988: 23) cautions that: "Preventing salary differences from generating feelings of second-class citizenship is essential to maintaining a common purpose among faculty."

The debate over the principle of pay-for-performance in an academic setting has largely occurred in the absence of explicit reference to the relative efficiency of alternative compensation schemes. Heneman (1992) argues that for merit plans to be both feasible and desirable, there must be a clear link between individual effort and performance; performance must be accurately measured; and higher pay must be an appropriate reward. Their success, therefore, depends on the nature of the work performed and the relative importance of competitive versus cooperative behaviour in the production process; on the capacity to measure output in a relatively inexpensive manner; and on the ability to provide clear financial signals consistent with the organization's objectives. If the rewards foster healthy competition among workers that raises productivity it may be a superior means of compensation relative to uniform pay increases; alternatively, if it undermines cooperative work processes, if output measures are inadequate, or the evaluation process is too costly or perceived to be biased, the potential productivity gains will not be realized.

This paper examines the application of merit pay plans in Canadian universities. It first reviews the theoretical justification for merit pay, and then summarizes its use in Canadian universities. Subsequently, the problems of implementing merit plans in an academic environment are considered. Finally, the incidence of merit pay is investigated. Since the objective functions of universities differ, compensation schemes can also be expected to vary. A logit analysis is conducted that finds weak support for the argument that merit pay is more prevalent among institutions with 
greater emphasis upon graduate training and research, and where the faculty is not unionized.

\section{MERIT PAY IN THEORY: SALARY INCREASES AS "PRIZES"}

Firms may choose among several methods of linking individual compensation to productivity. Piece-rate schemes pay a set amount per unit of output, and periodic evaluations assess individual output and adjust remuneration accordingly. Wages may be based upon continuous supervision and monitoring of worker effort or input, or it may be optimal to depart from a strict equality between wage rates and marginal productivity in order to foster greater workplace cooperation and increase worker loyalty to the firm. Both the literature on human resource management and agency theory emphasizes that the choice of compensation scheme will depend upon the nature of the production process, the relative cost of monitoring input and output, the attitude of workers towards salary equality and the compensation paid by competing firms.

Heneman (1992) defines merit awards as incentive pay that is based upon past performance and is designed to motivate future performance. Where individual employees are responsible for complete tasks with measurable effects on the total output of the firm, the links between rewards for past performance and future effort are strengthened; conversely, where teamwork is an important component of the production process, it is not only more difficult to evaluate individual performance, but financial rewards may not elicit the appropriate cooperative behaviour among employees. Moreover, financial rewards may diminish the intrinsic value individuals place upon their work; they may decrease the employees' selfesteem if they deem merit awards to be too infrequent or if they hold an inflated self-evaluation of their performance; or may generate the "Matthew effect" where the motivation of underperformers declines and overperformers experience a sense of guilt (Heneman 1992: 49-56).

Economists applying agency theory reach much the same conclusion. Lazear and Rosen (1981) characterize merit pay as a "rank-order tournament," where individuals compete for salary "prizes" on the basis of relative, rather than absolute, performance. Where it is difficult for firms to obtain an absolute measure of worker productivity, or where it is cheaper to obtain an relative measure, firms establish a competitive game among employees and reward the winners with a prize. They offer the example of a handful of junior executives vying for a senior executive position within a firm. Differences in performance may be marginal and the best that can be achieved is a ranking of individuals. By offering promotion and a raise to the most productive, an incentive is created for all 
competitors to increase their output. Although the winner's new salary may exceed his/her value to the firm, it is an efficient arrangement if the total increase in productivity of all contestants is sufficiently large to justify the winner's higher salary (Lazear and Rosen 1981). Similarly, merit pay schemes involve a zero-sum game relying upon a relative measure of output among contestants vying for a salary prize. A fixed pool of funds is distributed among employees exhibiting the greatest production over an interval of time with the "more exceptional" rewarded by transferring funds away from "less exceptional" performers.

If the salary prize induces enough greater effort, the value of the resulting increase in productivity exceeds the higher salary costs. Alternatively, if production relies upon a high degree of cooperation among employees - in the form of common tasks, or the transfer of knowledge through on-the-job training - merit pay may be inefficient. Rank-order tournaments based upon relative performance create an incentive to withhold cooperative effort. According to Lazear (1989: 578-9): "Workers benefit not only by their own successes but also their rivals' failures. Incentives exist, therefore, to making their opponents look bad." As the difference between the size of awards increases, and the relative importance of cooperation increases, the likely efficiency of a competitive game declines. And where sabotage is possible - such that one worker can adversely affect the output of another - the potential for the competitive game to be counterproductive increases. Lazear (1989: 562) concludes that: "It is not sensible to create rivalry by setting up implicit promotion contests between workers whose cooperation is important to the firm." In this case, seniority-based salary structures may be preferred by firms in order to eliminate competitive, noncooperative behaviour in the workplace.

Organizational culture, or the set of beliefs held by members of the organization, is also an important determinant of compensation systems. According to Lazear (1989: 561), "the most important interactions between workers relate to relative pay... The desire for similar treatment is frequently articulated as an attempt to preserve worker unity, to maintain good morale, and to create a cooperative workplace." Similarly, Heneman (1992) argues that a preference for uniform, rather than performancebased, pay may originate with employees; for instance, unionized workers tend to be more sceptical of subjective evaluations by supervisors; and unions, as political institutions, tend to favour salary compression to maintain solidarity among members. The latter conclusion is consistent with the findings of Freeman (1982) that there is a tendency for unions to reduce wage dispersion through standardized, seniority-based pay increments and to resist discretionary performance awards. 
When viewed in a narrow sense - as a reward based upon relative performance within a single firm - merit pay does not necessarily equate salaries with absolute measures of productivity. Hansen (1988) points out, however, that internal pay policies cannot be divorced from external labour market pressures and absolute measures of performance. A competitive labour market requires that a firm's compensation package be sufficiently high to recruit and retain employees. In the context of merit awards, this implies that the total value and distribution of awards by one firm must be sufficiently attractive to prevent the loss of employees to others. Inter-firm competition and labour mobility, therefore, generates a closer relationship between an individual's marginal productivity and compensation. In a similar vein, Heneman (1992: 8) argues that even where the success of merit pay is open to question, it remains an important symbol of an organization's culture, signalling a commitment to reward harder work. Ignoring the influence of the external market may raises the problem of self-selection. The structure of career earnings will play an important role in an individual's initial job choice and subsequently movement between firms. Firms with merit-based pay structures are likely to attract more aggressive, non-cooperative, risk-taking employees; risk-averse, cooperative employees are encouraged to seek employment at firms with more uniform pay structures where reward is based chiefly upon academic rank and seniority. The external market, therefore, may lead to a "clustering" in the pattern of compensation schemes among firms competing in the same regional labour market.

The general discussion of the desirability and feasibility of merit pay raises a number of questions for their application in universities. Is merit pay appropriate to the nature of academic work and the organizational culture of universities? Are there adequate methods of evaluation to support a merit-pay system that is deemed to be "equitable, balanced and fair?" (Pratt 1988). And if so, how large should the awards be relative to other forms of compensation, including cost of living increases, regular seniority-base pay increases, remedies for past inequities, and market supplements?

\section{MERIT PAY IN CANADIAN UNIVERSITIES}

Performance-based salary awards may be an appropriate means of directing faculty effort towards a university's objectives. Hansen (1988: 10) describes the role of merit pay schemes in precisely this manner: "The practice, ideally, encourages faculty members to devote their efforts to some combination of teaching, research, and service activities, in accordance with the institution's mission, thereby strengthening the institution 
and enhancing the benefits gained by students and society." In Canada, the majority of universities include a merit plan as one aspect of a formal salary structure that defines the rules and regulations governing faculty compensation. This includes salary ranges for each academic ranks; conditions and criteria for tenure and promotion; market supplements typically paid to faculty in disciplines with high non-academic salaries; equity funds to remedy salary anomalies; nonsalary benefits; and pension payments as a form of deferred earnings (Grant 1993).

How merit pay is integrated with the overall compensation system varies markedly among institutions. The chief distinction rests with the division of salary funds paid for "normal" career progress and for "meritorious" performance. Annual increments for career development (CDIs) or progressthrough-the-ranks (PTR), paid in recognition of satisfactory performance during the previous academic year, are nondiscretionary to the extent that payment can only be withheld in cases where performance is demonstrated to be unsatisfactory (Waterloo is the only university where salary "decrements" may occur in the event of unsatisfactory performance); in contrast, merit awards are discretionary payments for exceptional achievement during the previous year(s). Typically, a specific pool of money is set aside and distributed among deserving faculty members either by administrative fiat or a system of peer review. Among the 46 largest Canadian universities, 16 have no merit pay schemes; 6 have bonus awards (or one-time, lump-sum payments excluded from base salary); and 25 incorporate merit awards into an individual's base salary (Table 1).

Lump-sum bonus awards constitute a minor aspect of total compensation. A fund ranging from 2 to 16 percent of the monies available for normal CDIs, is established to provide for one-time awards that do not increase the recipient's base salary. These awards are typically small, usually less than a CDI. Carleton University has a unique plan where the awards are more substantial $(\$ 10,000)$ and paid in the form of a research grant or partial release from teaching duties.

Salary-based merit plans are far from homogeneous, varying according to standards for assessment, the total funds for distribution relative to "normal" CDIs, and the number and value of individual awards. In the most common case (TUNS, Guelph, Lakehead, Laurentian, Trent, Wilfrid Laurier, Windsor, Regina and Saskatchewan), a specified percentage of the faculty, ranging from 10 to 25 , must be deemed meritorious each year. The value of awards are predetermined, most frequently an additional CDI. At six universities (Concordia, McMaster, Alberta, Calgary, Lethbridge and Simon Fraser) CDI and merit awards are determined simultaneously, usually through a peer-review process. In each instance, a "par" increment defines the score for satisfactory performance and evaluation scores 
TABLE 1

Merit Pay Schemes in Canadian Universities, 1993

\begin{tabular}{|c|c|c|c|}
\hline University & Size of Award & Size of Merit Pool/Number of Awards & Merit $/ P T R^{*}$ \\
\hline \multicolumn{4}{|c|}{ A. Lump-Sum Bonus Awards } \\
\hline Dalhousie $^{1}$ & $\mathrm{CDI}$ & Professors above salary ceiling only & $\mathrm{n} / \mathrm{a}$ \\
\hline \multicolumn{2}{|c|}{ U. New Brunswick ${ }^{2}$ Open } & 1.2 x Asst. floor; per 610 members & $5 \%$ \\
\hline St. Thomas & $\$ 1,050$ or $\$ 2,100$ & $\$ 2,100$ per 60 members & $2 \%$ \\
\hline Carleton $^{2,3}$ & $\begin{array}{l}14 @ \$ 10,000 \\
6 @ \$ 1,000\end{array}$ & $\$ 146,000$ & $13 \%$ \\
\hline Manitoba & $\$ 2,000$ & 30 awards $(\$ 60,000)$ & $3 \%$ \\
\hline Winnipeg ${ }^{1}$ & Open & $\$ 60,000$ per 250 faculty & $16 \%$ \\
\hline \multicolumn{4}{|l|}{ B. Salary Awards } \\
\hline TUNS & $0.5,1$ or $1.5 \mathrm{CDI}$ & 25 CDI per 100 faculty & $25 \%$ \\
\hline Bishop's & CDI & Apparently unrestricted & $\mathrm{n} / \mathrm{a}$ \\
\hline Concordia & approx. $\$ 20-500$ & PTR/Merit evaluation & $20 \%$ \\
\hline McGill $^{4}$ & .33 or $.67 \mathrm{CDI}$ & PTR/Merit evaluation (average = 1.33) & $33 \%$ \\
\hline Brock & $\$ 500, \$ 1000$ or $\$ 1500$ & $1 \%$ of salary base & $50 \%$ \\
\hline Guelph & CDI & $25 \%$ of faculty & $25 \%$ \\
\hline Lakehead & CDI & $10 \%$ of faculty & $10 \%$ \\
\hline Laurentian & CDI & $10 \%$ of faculty & $10 \%$ \\
\hline McMaster & $0.5,1$, or $1.5 \mathrm{CDI}$ & PTR/Merit Evaluation (average $=1.2$ ) & $20 \%$ \\
\hline Queen's & multiples of 0.1 CDI & PTR/Merit evaluation (average $=1.0$ ) & $100 \%$ \\
\hline Toronto & multiples of $\$ 100$ & Annual performance appraisal & $100 \%$ \\
\hline Trent & CDI & 39 per 200 members & $20 \%$ \\
\hline Waterloo & Open & PTR/Merit evaluation (average $=1.0$ ) & $100 \%$ \\
\hline Western & Open & $1 \%$ of salary pool & $33 \%$ \\
\hline Wilfrid Laurier & CDI & $10-12 \%$ of faculty & $11 \%$ \\
\hline Windsor & 1 or $2 \$ 1,000$ units & 95 units per 500 faculty & $15 \%$ \\
\hline York & Open & $0.5 \%$ of salary base & $20 \%$ \\
\hline Regina & CDI & Maximum of 2 per individual per rank & $10 \%$ \\
\hline U. Saskatchewan & $0.5,1,1.5$ or 2 CDI & 170 x CDI for Full Professor & $25 \%$ \\
\hline U. Alberta & 1 or 2 CDI & PTR/Merit Evaluation (average $=1.1 \mathrm{CDI}$ ) & $10 \%$ \\
\hline Calgary & multiples of .2 CDI & PTR/Merit Evaluation & $60 \%$ \\
\hline Lethbridge & 0.5 or $1 \mathrm{CDI}$ & PTR/Merit Evaluation (average $=1.15 \mathrm{CDI}$ ) & $15 \%$ \\
\hline UBC & Apparently open & $1 \%$ of salary base & $33 \%$ \\
\hline Simon Fraser & 0.5 or $1 \mathrm{CDI}$ & PTR/Merit Evaluation (average $=1.3 \mathrm{CDI}$ ) & $30 \%$ \\
\hline \multirow[t]{2}{*}{ Victoria $^{5}$} & $\mathrm{RI} 1=.75 \mathrm{CDI}$ & $75 \%$ of faculty & \\
\hline & $\mathrm{RI} 2=.75 \mathrm{CDI}$ & $15 \%$ of faculty & $68 \%$ \\
\hline
\end{tabular}

* Value of the merit pool relative to the funds for normal career development increments (CDIs or PTRs).

1. Merit awards for Full Professors raise the salary ceiling by one CDI step.

2. May be taken as a research grant.

3. 14 awards for teaching and research (\$10,000 each) and 6 for professional service $(\$ 1,000)$.

4. $\mathrm{CDI} / \mathrm{Merit}$ awards are in units of $0.2 \mathrm{CDI}$, where satisfactory $=0.4 \mathrm{CDI}$; the average award $=$ 1.0 CDI and awards rarely exceed 1.6 CDI.

5. Victoria also has a bonus scheme.

Source: Canadian Association of University Teachers, Salary files. 
in excess of the par value may receive additional partial or whole CDIs. At Lethbridge, for instance, the par increment equals 1.0 and the average score for a department or faculty cannot exceed 1.15 . Thus for every ten faculty members, 11.5 increments can be awarded and, assuming that none receive unsatisfactory ratings, $1.5 \mathrm{CDI}$ units are available for merit awards. More flexible plans exist at Brock, Western, York and UBC: the size of the merit pool is specified (from 0.5 to 1.0 percent of total salary base) with no apparent restrictions on the number or value of individual rewards. Merit awards tend to be a larger percentage of total compensation, equivalent to 25-50 percent of CDI/PTR funds. Unique plans are in place at McGill and Victoria. Faculty at McGill receive annual salary increments in multiples of $\$ 400$, ranging from $\$ 0$ to $\$ 2,000$, with the restriction that no more than 30 percent of awards can come from a single category. At Victoria, a two-tiered merit system prevails on top of normal CDIs: 60 percent of faculty receive an additional award equal to $.75 \mathrm{CDI}$; and 15 percent receive an extra 1.5 CDI.

In contrast to the above plans where merit awards are paid in addition to a basic CDI, three universities replace CD/PTR plans with purely discretionary merit awards as the sole basis of career salary progress. Waterloo and Queen's refer to annual "average selective increments" with individual awards varying around the average. Since there is no predetermined amount for satisfactory performance, all awards are theoretically discretionary. Queen's describes its plan as "equal pay for equal merit": the only restriction on awards is that they must be in multiples of 0.1 of the average selective increment. A similar plan exists at Toronto: the pool of money for career development is the subject of regular negotiations and merit awards are paid in units of $\$ 100$. The unique feature of these schemes is that compensation is based strictly on relative performance, with above-average selective increment awards financed by transferring income away from those with below-average selective increments.

Roughly two-thirds of Canada's largest universities, therefore, have embraced some form of performance-based pay, either incorporated into an individual's salary or, in a handful of cases, as a one-time bonus award. In most cases, it is a minor aspect of the overall compensation system: the merit "pool" is less than 25 percent of funds available for "normal" career progress (CDIs or PTRs). In three cases, however, merit awards constitute the sole form of career progress. Determination of the size and recipient of awards also varies, from peer-reviewed performance evaluations, to the discretion exercised by Department Chairs and Deans. Why some universities have adopted merit pay while other have not, and why plans vary in detail, may depend upon perceptions of how effectively such plans can be implemented. 


\section{VARIATIONS AMONG INSTITUTIONS: PROBLEMS IN}

IMPLEMENTATION

The movement towards merit-based pay systems in American universities has been described as "slow and painful": largely abandoned in the 1930s and 1940s in favour of standard seniority-based increases that were easier to administer, they gained renewed popularity after 1950. Despite the expressions of support for merit pay by some administrators, particularly within business schools (Prewitt, Phillips and Yasin 1991), it is deemed by others as "pestiferous and professionally demoralizing" (Hoko 1988: 29). And while the data on merit pay in American universities in limited, the most exhaustive survey finds a "preponderance of evidence of merit plan failure," largely due to problems of implementation (Taylor, Hunnicutt and Keeffe 1991: 52).

Similar views are expressed in Canadian universities, albeit with less exuberance. Most complaints stem from the difficulty in translating the university's objective function into clear, financial signals. A committee at the University of Guelph reported that: "Surveys of the Faculty have repeatedly found that faculty: a) support merit evaluations, and b) dislike and distrust the present system [due to] variable departmental rating distributions, changing amounts available for distribution, varying dispersal schemes" (CAUT 1993). If the evaluation system is unpredictable, or the rules of the game are deemed to be biased, a merit plan will not evoke the correct response from faculty and, indeed, may engender sufficient discontent to be counterproductive. Defining unambiguous measures of faculty performance is a long-standing problem, elegantly expressed by a committee at the University of Alberta:

A university evaluation system, to be effective, must avoid both the scylla of encouraging popular instruction (without emphasis on required reflective inquiry)... as well as the Charybdis of rewarding only the quantified measure of publication of research to the detriment of both scholarship and teaching (University of Alberta 1991).

Codification of evaluation schemes that emphasize simple, quantifiable output measures may distort the academic function: if teaching performance is more difficult to assess, the institution may misspecify the relative importance place upon instruction; measuring research in terms of total journal pages without distinguishing between quality of journals encourages high quantity, low quality publications; and incentives must be sufficiently flexible to recognize different career paths, particularly in universities that have evolved from primarily teaching to teaching/ research institutions. 
The chief distinction between the objectives of institutions is the relative emphasis placed upon teaching and research. This may lead to differences in career-earnings profiles: "The argument is that research and thesis-supervision skills generally require a more extended period to develop than teaching skills, so that schools with a research orientation will have earnings profiles which fan out in comparison with schools which emphasize teaching" (Johnson and Stafford 1974: 560-1). But differences in compensation schemes may also stem from the capacity to measure productivity. For research-oriented institutions, seeking to attract both graduate students and research funds, evaluation of faculty performance is not only easier to quantify, but there is a clearer link between faculty output and the benefits derived by the institution; in contrast, measuring individual teaching performance is notoriously difficult. One review of the literature on academic salary determination found that "student evaluations, class enrolments, credit hours generated, and student achievement are limited measures of teaching effectiveness," and attributed the insignificant impact of teaching performance on salaries to the "widely distrusted and generally incomplete" mechanisms for evaluation (Kasten 1984: 501). Accordingly, exceptional teachers generally command a small or no salary premium (Kasten 1984), since "excellence in research is what truly matters" in salary determination (Gregorio, Lewis and Wanner 1982). This is also consistent with the argument that larger, more diversified institutions find it more difficult to monitor input and thus place greater emphasis upon output-based measures (Brown 1990; Nalebuff and Stiglitz 1983; Schwab and Olson 1990).

If faculty respond appropriately to financial incentives, and the production process is enhanced by individual competition, performancebased pay may be the best means of structuring incentives; however, if faculty cooperation and collegiality are discouraged, it may "undermine such virtue as is present in the system" (Brennan and Pettit 1991). Freeman (1979) argues that the traditional view of the university as a "community scholars" is reflected in salary policies that explicitly resist paying differential salaries by discipline. "Market supplements" or "loadings" based upon the market's valuation of labour is replaced by an "intellectual value structure" that judges individuals "according to intellectual quality and scholarly output with differences in market prices ignored." This does not preclude differential pay for faculty - indeed, it is argued that most academics support the view that some members are more productive than others and should be rewarded accordingly (OCUFA 1978) but salaries are typically tied to traditional promotion decisions and seniority. 
A central question, in this regard, is who does the evaluating. In many instances, faculty unionization and formal salary structures were designed to limit administrative discretion and perceived favouritism in salary determination. According to a faculty member at the University of Ottawa: "A long, yet still remembered, history of abuse (real or imagined) of a previous merit scheme by department chairs and deans has made merit a very dirty words around here" (CAUT 1993). Peer review is thus portrayed as the "crucial safeguard" to the propriety of merit schemes but can involve onerous, time-consuming procedures that threaten to dissipate any potential merit-induced productivity gains: many merit pay schemes take all of the gnashing of teeth that occurs at tenure and promotion times, and replicates it in miniature each evaluation year.

Consider, for instance, the undertakings required to mete out CDI/ merit awards at Concordia University. First, a member's evaluation score is determined according to the following steps:

a) each member selects a set of numerical weights, ranging from 0.1 to 0.8 and totalling 1.0 , assigned to the three categories of teaching, research and service;

b) the Department Personnel Committee (DPC) evaluates the performance of each member, assigning values from 0 to 3 in each category;

c) the individual's scores are aggregated, according to the weights chosen by the member or assigned by the committee, with the average for the Department not to exceed 2.0;

d) the DPC's evaluations are forwarded to the Faculty Personnel Committee (FPC);

e) the FPC conducts its own evaluation, with a total of 0.5 points times the number of faculty members to distribute; it may add from 0.1 to 3.0 points to a member's score in recognition of outstanding performance, may not reduce anyone's point score, and may not raise anyone's score above 4.0;

f) senior administration may allocate up a total of 0.1 points times the number of member to ensure equitable treatment across faculties; a maximum of 0.5 may be awarded to one member, and no one's score may exceed 4.0 .

Having arrives at evaluation score, annual salary increments are awarded. They range from 3 percent of the Assistant salary floor (approximately $\$ 1,100$ ) to a maximum amount which depends upon the size of the salary pool (usually between $\$ 1,400$ and $\$ 1,600$ ). This procedure, which involves an appeal procedure at each stage, has the redeeming fea- 
ture that reviews are conducted only in odd-numbered years and the same increment applies for two years.

In contrast, merit plans that rely solely upon administrative decision making may be less expensive, but are vulnerable to the problem that the evaluator, usually the Department chair, may encounter difficulty in justifying awards. The discretionary merit plan at the University of Toronto offers a case in point. In 1980, President Strangway counselled senior administrators to provide a careful written rationale for salary awards:

There have been a number of grievances over merit pay and in several cases, one of the reasons for initiating the grievance was because the faculty members was not clearly informed of the reason for the [low] award. One issue that has arisen is whether a low merit award is a penalty for improper conduct or whether it is for lack of accomplishment. In a general way, recent judgements suggest that the main ground for low awards be for lack of accomplishment (OCUFA 1980).

Faculty members' resistance to merit pay, either because they favour a cooperative workplace or seek to limit administrative discretion, may be reflected in the propensity for unionization. Consistent with this view is the finding that salary dispersion in American universities is much smaller in unionized faculties, to the point of accepting lower mean salaries to accomplish this end (Kesselring 1991; Rees 1993; for Canadian universities, see Rees, Kumar and Fisher 1995).

Finally, the academic labour market exhibits a degree of regional segmentation. On the demand side, many universities have a common provincial funding base; and on the supply side, the cost of living, the salaries of alternative occupations, and the supply of new Ph.D.'s differ between areas despite the mobility of academics. Ault, Rutman and Stevenson (1982), for instance, found strong regional biases in the market for academic economists. The market in Canada is further fragmented by the primary language of instruction, with Laval, Montréal, Université du Québec, Sherbrooke, and, to a lesser extent, Laurentian and Moncton, competing in a more limited market for francophone or bilingual professors. This is expected to generate similarities in compensation within regionally- or language-based labour markets, and potential differences between market segments. In Atlantic Canada, only the Technical University of Nova Scotia (TUNS) has a salary-based merit plan; in Quebec, the three Englishlanguage institutions (Bishop's, Concordia and McGill) offer discretionary salary awards, and three French-language schools do not; and in Ontario and the western provinces, merit pay schemes predominate.

Variation among compensation systems in Canadian universities from individual salary increases based strictly upon academic rank and seniority, to annual performance-based increases - may, therefore, reflect 
four important differences among institutions: a) the nature of the production process, arising particularly from the relative emphasis upon teaching and research; b) the capacity to measure and monitor performance in an inexpensive manner; c) faculty preference for salary equity; and d) the external market in which it competes for academic labour. This argument can be applied to estimate the determinants of merit plans in Canadian universities.

\section{A LOGISTIC ANALYSIS OF THE DETERMINANTS OF MERIT PAY}

The probability that an institution has a salary-based merit scheme $\left(\mathrm{p}_{\mathrm{i}}\right)$ is estimated according the cumulative logistic probability equation:

$$
\mathrm{Z}_{\mathrm{i}}=\mathrm{F}\left(\alpha+\beta \mathrm{X}_{\mathrm{i}}\right)
$$

where $\mathrm{Z}_{\mathrm{i}}=\log \left[\mathrm{p}_{\mathrm{i}} /\left(1-\mathrm{p}_{\mathrm{i}}\right)\right], \beta$ represents institutional characteristics, and $\mathrm{X}_{\mathrm{i}}$ is a vector of parameters (Maddala 1983).

The likelihood of a merit plan is expected to increase with the relative emphasis upon research and graduate training $\left(\mathrm{GRAD}_{\mathrm{i}}\right)$, increase with the number of faculty members $\left(\mathrm{SIZE}_{\mathrm{i}}\right)$, decline in the presence of a unionized bargaining association $\left(\mathrm{UNION}_{\mathrm{i}}\right)$, and vary according to region (ATL, ONT/QUE, WEST) and whether French is the primary language of instruction $\left(\mathrm{FRANCO}_{\mathrm{i}}\right)$. These parameters are defined as follows:

$G R A D_{i}$. The percentage of graduate students in total enrolment is taken as a proxy for the degree of research orientation at a university. The probability of a merit-pay plan is expected to increase with the importance on research for two reasons: a closer link between faculty output and benefits accruing to the university; and greater ease in measuring output.

$S I Z E_{i}$. A commonly cited indicator of the relative cost of evaluating employee output relative to observing directly individual effort, is establishment size (Brown 1990). Accordingly, it is expected that universities with larger, more diversified faculties will tend to favour meritbased pay schemes.

$U N I O N_{i}$. Canadian university faculties can be divided into three categories of bargaining status. In the majority of institutions, unions exist by statute, with the rights and responsibilities of a trade union defined under the provincial labour relations act. In the Province of Alberta, faculty associations at the three universities have bargaining rights not covered by statute, but are recognized voluntarily by the employer. Their bargaining status is probably more akin to nonunionized status given their proclivity to rely upon arbitrated rather than negotiated settlements. And in fourteen universities, the faculty is not unionized, 
although it is usually party to a consultative process in establishing terms and conditions of employment. The presence of a unionized faculty association is taken as a proxy for workplace culture and, specifically, the preference for uniform, seniority-based pay increases rather than pay-for-performance.

$R E G I O N\left(A T L_{i}, O N T / Q U E_{i}, W E S T_{i}\right)$. A common dependence on provincial funding and locally-segmented labour markets may influence the pattern of employer-employee relations. Three regional dummy variables are included to approximate regional labour markets.

FRANCO. Since the principal language of instruction further segments the market for academic labour, a dummy variable is included that takes on the value of 1 for French-language institutions, 0.5 for bilingual institutions, and 0 for English-language institutions.

Data for the 46 institutions in the sample for 1993 are summarized in Table 2. Roughly half of universities have salary-based merit pay as an aspect of compensation. There is a significant variation in the size of institutions, with the number of full-time faculty members (excluding staff in medical schools and with administrative duties) ranging from 78 to 1,954, and with a mean of 633 . The variation in the emphasis upon graduate training is also large, ranging from 0 to 26.1 percent of total student enrolment, with a mean of 7.8 percent. Unionized faculty associations exist in 63 percent of

TABLE 2

\section{Summary of Data}

\begin{tabular}{llccc}
\hline Variable & Units of Measure & Minimum & Maximum & Mean \\
\hline MERIT & $\begin{array}{l}1=\text { salary-based merit plan } \\
\text { S } \text { otherwise }\end{array}$ & 0 & 1 & 0.54 \\
SIZE & Number of faculty members & 78 & 1,954 & 633 \\
GRAD & Graduate students as \% of total & 0 & 26.1 & 7.8 \\
& FTE & & & \\
UNION & $1=$ certified bargaining unit & 0 & 1 & 0.61 \\
& $0=$ otherwise & & & \\
FRANCO & $1=$ francophone & 0 & 1 & 0.13 \\
& $1 / 2=$ bilingual & 0 & $1 / 2$ & 0.07 \\
Region & $0=$ anglophone & 0 & 1 & 0.80 \\
ATLANTIC & 0 or 1 & & & \\
ONT/QUE & 0 or 1 & 0 & 1 & 0.28 \\
WEST & 0 or 1 & 0 & 1 & 0.50 \\
\hline $\mathrm{n}=46$ & & 0 & 1 & 0.23 \\
\hline
\end{tabular}


institutions; there are 6 francophone, 3 bilingual, and 37 anglophone schools; and 28 percent of schools are in the Atlantic region, 50 percent in Ontario and Quebec, and 23 percent in western Canada.

The regression results are summarized in Table 3 . The data was fitted to three separate equations using the iterative maximum likelihood process. The regional dummy excluded from each equation affects only the size of the constant term and the coefficients on the regional dummies. Interpreting Equation 3, the results are dominated by the language and regional dummy variables, with the likelihood of a merit scheme greater in Ontario/ Quebec and the West, and lower in Atlantic Canada and among primarily francophone institutions. As predicted, the absence of a unionized faculty association and a greater emphasis upon graduate training increases the probability of a merit scheme; however, the coefficient on the SIZE variable did not have the predicted sign, with the likelihood of a merit scheme declining with the number of faculty members. All of the variables were significant at a 90 percent level of confidence with the exception of SIZE.

TABLE 3

Regression Results, Logistic Analysis

\begin{tabular}{|c|c|c|c|}
\hline \multicolumn{4}{|c|}{ Dependent Variable: Merit } \\
\hline \multirow[b]{2}{*}{ Independent Variable } & \multicolumn{3}{|c|}{ Estimated Coefficient (absolute value of t-statistic) } \\
\hline & Equation 1 & Equation 2 & Equation 3 \\
\hline \multirow[t]{2}{*}{$\overline{\text { SIZE }}$} & -0.004 & -0.004 & -0.004 \\
\hline & $(1.51)$ & $(1.51)$ & $(1.51)$ \\
\hline \multirow[t]{2}{*}{ GRADUATE } & 0.300 & 0.300 & 0.300 \\
\hline & $(1.94)^{*}$ & $(1.94)^{*}$ & $(1.94)^{*}$ \\
\hline \multirow[t]{2}{*}{ UNION } & -3.297 & -3.297 & -3.297 \\
\hline & $(1.76)^{*}$ & $(1.76)^{*}$ & $(1.76)^{*}$ \\
\hline \multirow[t]{2}{*}{ FRANCOPHONE } & -6.947 & -6.947 & -6.947 \\
\hline & $(2.52) * *$ & $(2.52) * *$ & $(2.52)^{* *}$ \\
\hline \multirow[t]{2}{*}{ ATLANTIC } & -5.283 & -7.587 & \\
\hline & $(2.24) * *$ & $(2.60) * *$ & \\
\hline \multirow[t]{2}{*}{ ONTARIO/QUEBEC } & 2.303 & & 7.587 \\
\hline & (1.47) & & $(2.60)^{* *}$ \\
\hline \multirow[t]{2}{*}{ WEST } & & -2.303 & 5.283 \\
\hline & & (1.47) & $(2.24)^{* *}$ \\
\hline \multirow[t]{2}{*}{ CONSTANT } & 3.606 & 5.909 & -1.677 \\
\hline & (1.57) & $(2.03)^{* *}$ & (1.04) \\
\hline Maddala $\mathrm{R}^{2}$ & 0.59 & 0.59 & 0.59 \\
\hline $\mathrm{df}$ & 40 & 40 & 40 \\
\hline
\end{tabular}

* Significant at 90 per cent level of confidence.

** Significant at 95 per cent level of confidence. 
Since the dependent variable is the log-odds ratio (or $\log \left[p_{i} /\left(1-p_{i}\right)\right]$ ), the effect of a change in explanatory variable $x_{j}$ on the probability of a merit plan can be approximated as $\delta \mathrm{P}_{\mathrm{i}} / \delta \mathrm{x}_{\mathrm{ij}}=\beta_{\mathrm{i}}\left[\mathrm{p}_{\mathrm{i}}\left(1-\mathrm{p}_{\mathrm{i}}\right)\right]$. Because regional dummies overwhelm the results, the influence of GRAD and UNION are isolated. In Table 4, two representative English-language institutions are defined: a) a small undergraduate school with 300 faculty members and no graduate students; and b) a larger institution with 1,000 faculty members, and graduate programs accounting for 10 percent of student enrolment. Unionization has a marginal influence of the likelihood of a merit plan in Atlantic Canada (from 6 to 8 percent) and Ontario/Quebec (12 to 17 percent), and a pronounced impact in Western Canadian universities (54 to 61 percent).

TABLE 4

Estimated Probability of a Merit Plan, by Type of Institution

\begin{tabular}{lcccc}
\hline & \multicolumn{2}{c}{ Small Undergraduate School } & \multicolumn{2}{c}{ Large $^{l}$ Graduate School $^{2}$} \\
\cline { 2 - 5 } & Union & Non-Union & Union & Non-Union \\
\hline Atlantic & 0.2 & 5.8 & 0.4 & 8.7 \\
Ontario/Quebec & 81.8 & 99.2 & 87.4 & 99.5 \\
West & 31.0 & 92.4 & 40.9 & 94.9 \\
\hline
\end{tabular}

1. Defined as SIZE $=300, \mathrm{GRAD}=0 \%$, FRANCO $=0$

2. Defined as $\mathrm{SIZE}=1,000, \mathrm{GRAD}=10 \%, \mathrm{FRANCO}=0$.

Table 5 displays the influence of graduate training on a "representative" English-language institution with 500 faculty members. The differences are more profound outside Atlantic Canada and display a strong interaction between union status and graduate training. In Ontario/Que$\mathrm{bec}$, for instance, the probability of a unionized institution having a meritpay plan rises from 26 to 87 percent as the percentage of graduate students rises from 0 to 10 percent of total enrolment.

TABLE 5

Impact of Graduate Training and Unionization on Estimated Probability of a Merit Plan ${ }^{1}$

\begin{tabular}{lcclccc}
\hline & \multicolumn{2}{c}{ Atlantic Canada } & \multicolumn{2}{c}{ Ontario/Quebec } & \multicolumn{2}{c}{ Western Canada } \\
\cline { 2 - 7 } & Union & Non-Union & Union & Non-Union & Union & Non-Union \\
\hline GRAD $=0 \%$ & 0.0 & 0.4 & 25.6 & 90.3 & 3.3 & 48.3 \\
GRAD $=5 \%$ & 0.0 & 2.0 & 61.0 & 97.7 & 13.4 & 80.7 \\
GRAD $=10 \%$ & 0.4 & 8.7 & 87.4 & 99.5 & 40.9 & 94.9 \\
\hline
\end{tabular}

1. Where SIZE $=500$, FRANCO $=0$. 
The overall results can be summarized as follows:

- The regional and language dummy variables dominate the probability of a merit-pay scheme. This may reflect a "clustering" of similar compensation systems in localized labour markets where there is greater mobility between institutions, for reasons of either language or proximity. Alternatively, this may simply be a function of the unique historical evolution of universities in different regions of the country.

- The size of the institution, measured in terms of the number of faculty members, had no significant impact on the likelihood of a merit pay plan.

- The results provide weak support for the argument that merit pay schemes are more prevalent at institutions with large graduate programs. This is consistent with two arguments outlined above: that merit awards are a more effective vehicle for motivating performance in research-oriented institutions, and that exceptional research is more readily measured than exceptional teaching.

- The presence of a unionized bargaining agent for the faculty tends to diminish significantly the likelihood of a merit-pay plan. This may reflect employees' preference for a more cooperative workplace and for seniority-based pay increases that reduce income differentials among faculty members.

\section{CONCLUSION}

As universities face greater restrictions in public funding, and administrators seek greater discretion over salary determination, departures from traditional seniority-based compensation systems can be anticipated. Merit pay schemes, however, offer no panacea. While the principle of performance-based pay receives some support, implementation of merit plans has proved more intractable. Their appropriateness will depend upon the capacity to structure a system of monitoring and rewarding faculty output that is inexpensive, perceived by faculty to be "fair," and compatible with the institution's objectives and workplace culture.

The incidence of merit pay plans in Canadian universities reinforces the view that institutions with a greater emphasis upon research relative to teaching, where output is "easier" and less costly to measure, will tend to favour pay-for-performance plans. In contrast, where there is distrust of administrative discretion and pressure from faculty associations for more uniform compensation based upon a definition of satisfactory performance, faculty opposition may dissipate the potential productivity gains. Any change in compensation schemes, therefore, is likely to occur slowly and only in the face of significant resistance. 


\section{REFERENCES}

AUlT, D. E., G. L. RUTMAN and T. STEVENSON. 1982. "Some Factors Affecting Mobility in the Labor Market for Academic Economists." Economic Inquiry, Vol. 20, 104-133.

BrennAN, G. and P. PETTit. 1991. "Modelling and Motivating Academic Performance." Australian Universities Review, Vol. 34, No. 1, 4-9.

BROWN, C. 1990. "Firms' Choice of Method of Pay." Industrial and Labor Relations Review, Vol. 43, 165s-182s.

CANADIAN ASSOCIATION OF UNIVERSITY TEACHERS (CAUT). 1993. Merit Pay File.

FreEMAN, R. B. 1979. "The Job Market for College Faculty." Academic Rewards in Higher Education. D. R. Lewis and W. E. Becker, Jr., eds. Cambridge, Mass.: Ballinger.

FREEMAN, R. B. 1982. "Union Wage Practices and Wage Dispersion within Establishments." Industrial and Labor Relations Review, Vol. 36, 3-39.

GRANT, H. M. 1993. Salary Structures in Canadian Universities. Ottawa: Canadian Association of University Teachers.

GREGORIO, D. I., L. S. LEWIS, and R. A. WANNER. 1982. "Assessing Merit and Need: Distributive Justice and Salary Attainment in Academia." Social Science Quarterly, Vol. 63, 492-505.

HAMERMESH, D. S. 1988. "Salaries: Disciplinary Differences and Rank Injustices." Academe, May-June, 20-25.

HANSEN, W. L. 1988. "Merit Pay in Higher Education." Academic Labor Markets and Careers. D. W. Breneman, ed. New York: The Falmer Press.

HANSEN, W. L. 1988a. "Merit Pay in Structured and Unstructured Salary Systems." Academe, Nov./Dec., 10-12.

HASKELL, M. A. 1980. "Market and Merit Factors in the Determination of Academic Salaries." Journal of Industrial Relations, Vol. 22, 168-180.

Heneman, R. L. 1992. Merit Pay: Linking Pay Increases to Performance Ratings. Reading, Mass.: Addison Wesley.

HOKO, J. A. 1988. "Merit Pay: In Search of the Pedagogical Widget." The Clearing House, Vol. 61, No. 1, 29-31.

JOHNSON, H. G. 1974. "The Current and Prospective State of the Economics." Australian Economic Papers, Vol. 13, 1-27.

JOHNSON, G. E. and F. P. STAFFORD. 1974. "Lifetime earnings in a professional labor market: academic economists." Journal of Political Economy, Vol. 82, 549-569.

KASTEN, K. L. 1984. "Tenure and Merit Pay as Rewards for Research, Teaching, and Service at a Research University." Journal of Higher Education, Vol. 55, 500-514.

KESSELRING, R. G. 1991. "The Economic Effects of Faculty Unions." Journal of Labor Research, Vol. 12, 61-71. 
LAZEAR, E. P. 1989. "Pay Equality and Industrial Politics." Journal of Political Economy, Vol. 97, 561-580.

LAZEAR, E. P. and S. ROSEN. 1981. "Rank-Order Tournaments as Optimum Labor Contracts." Journal of Political Economy, Vol. 89, 841-864.

MADDALA, G. S. 1983. Limited-Dependent Variables and Qualitative Analysis in Econometrics. Cambridge: Cambridge University Press.

NALEBUfF, B. and J. E. STIGLITZ. 1983. "Prizes and Incentives: Towards a General Theory of Compensation and Competition." Bell Journal of Economics, Vol. 14, 21-43.

ONTARIO CONFEDERATION OF UNIVERSITY FACULTY ASSOCIATIONS (OCUFA). 1978. Salary and Benefits Working Papers, 1979-80. Toronto.

OCUFA. 1980. Merit Pay File.

PRATT, L. R. 1988. "Merit Pay: Reaganomics for the Faculty?" Academe, November-December, 14-16.

PREWITT, L. B., J. D. PHILLIPS and K. YASIN. 1991. "Merit Pay in Academia: Perceptions from the School of Business." Public Personnel Management, Vol. 20, 409-417.

REES, D. I. 1993. "The Effects of Unionization on Faculty Salaries and Compensation: Estimates for the 1980s." Journal of Labor Research, Vol. 14, 399-422.

REES, D. I., P. KUMAR and D. W. FISHER. 1995. "The Salary Effect of Faculty Unionism in Canada." Industrial and Labor Relations Review, Vol. 48, 441451.

SCHWAB, D. P. and C. A. OLSON. 1990. "Merit Pay Practices: Implications for Pay-Performance Relationships." Industrial and Labor Relations Review, Vol. 43, 237s-255s.

TAYlOR, R. L, G. G. HunnicutT and M. J. KeEFE. 1991. "Merit Pay in Academia: Historical Perspective and Contemporary Perceptions." Review of Public Personnel Administration, Vol. 11, No. 3, 51-65.

UniVERSity OF AlBERTA. Agreement Review Committee. 1991. "An Alternative System of Career Progress and Evaluation of Performance for Faculty: Principles for Consideration."

\section{RÉSUMÉ}

Le salaire au mérite dans les universités canadiennes

Nous examinons l'application de programmes de salaire au mérite dans les universités canadiennes et leur utilité comme méthode de structuration de la rémunération en contexte universitaire. Conçus comme une compétition pour motiver et rémunérer les différences de 
productivité entre les professeurs, leur efficacité dépendra de l'importance relative d'un comportement compétitif versus coopératif de ceuxci et de la capacité de construire une procédure d'évaluation qui fournit un instrument clair, non biaisé et abordable de mesure de la production. Si le rendement des professeurs est encouragé par la concurrence, si des signaux financiers clairs sont offerts et si le système d'évaluation est perçu comme étant juste, alors le salaire au mérite peut être un moyen efficace de structurer la rémunération. D'un autre côté, si on décourage les comportements coopératifs, si on ne peut pas mesurer la production de façon efficace et abordable et si les récompenses sont perçues comme biaisées, le salaire au mérite va gâcher la collégialité et nuire à la productivité.

Les différences entre universités - eu égard à leur emphase relative sur les études graduées et sur la recherche versus les études sous graduées, leur capacité de mesurer le rendement et la culture de travail peuvent produire des différences dans les méthodes de rémunération. Parmi les 46 plus grandes universités canadiennes étudiées, 16 n'avaient aucun programme de salaire au mérite, 6 recouraient à des systèmes de bonus forfaitaires non intégrés à la structure de salaires et 25 incorporaient des récompenses au mérite aux salaires individuels de base. Parmi ces dernières, nous notons une différence significative dans l'importance des récompenses, la quantité d'argent réservée à ces récompenses et les moyens pour identifier le rendement méritoire. Le plus souvent cependant l'évaluation était conduite par un système de jugement des pairs, les récompenses équivalaient à un avancement d'échelon ou de classe et on mettait de côté entre 10 et 25 \% des fonds réservés aux augmentations salariales annuelles pour les récompenses au mérite.

Nous utilisons ensuite une analyse logique pour évaluer la probabilité qu'une institution adopte un programme de salaire au mérite. Deux facteurs tendent à dominer les résultats : la langue (les universités francophones ayant moins tendance à recourir au salaire au mérite) et la région (où le salaire au mérite est virtuellement absent des provinces atlantiques et plus présent en Ontario et au Québec). D'importance secondaire, la probabilité de voir un programme de salaire au mérite augmente avec l'emphase sur les études graduées et la recherche et diminue lorsque les professeurs sont syndiqués. Cela suggère qu'alors que les systèmes de rémunération peuvent être historiquement déterminés, l'adoption d'un système de salaire basé sur le rendement rencontrera plus de résistance dans ces universités où l'emphase est mise sur les études graduées et où les professeurs sont syndiqués. 


\section{RESÚMEN}

Concursos Académicos ? Sueldo de acuerdo al mérito en las universidades canadienses

Este documento examina la aplicación de el sueldo de acuerdo al mérito en las universidades canadienses. Diseñado para motivar y recompensar la mayor productividad, la efectividad del sueldo de acuerdo al mérito depende de la importancia relativa del comportamiento competitivo comparativamente al comportamiento cooperativo del régimen de trabajo académico, la capacidad de evaluar el trabajo individual, y la capacidad de diseñar señales financieras claras en acuerdo con los objetivos de la institución. Diferencias entre universidades, relacionadas con el énfasis relativo que existe entre la preparación de estudiantes de segundo y tercer ciclo / investigación y la preparación de estudiantes de primer ciclo, la habilidad que la universidad tienen para medir la eficacia, y la cultura de trabajo son factores que influencian la manera como la retribución financiera es asignada. Un análisis detallado fue realizado, este análisis sugiere que la probabilidad de que una universidad tenga un sistema de pago al mérito varia de acuerdo a la región, aumentado cuando el énfasis es puesto en la educación de segundo y tercer ciclo y disminuyendo cuando los profesores forman parte de un sindicato. Esto sugiere que la adfopci0on de este tipo de paga puede encontrar mas resistencia en universidades con alto porcentajes de estudiantes de primer ciclo o con cuerpos profesionales sindicalizados. 